\title{
Vito Messina, Jafar Mehr Kian. "The sanctuary and cemetery of Shami: research of the Iranian-Italian joint expedition in Khuzistan at Kal-e Chendarin"
}

\section{Leonardo Gregoratti}

\section{(2) OpenEdition Journals}

Electronic version

URL: https://journals.openedition.org/abstractairanica/51787

DOI: 10.4000/abstractairanica. 51787

ISSN: 1961-960X

Publisher:

CNRS (UMR 7528 Mondes iraniens et indiens), Éditions de l'IFRI

\section{Electronic reference}

Leonardo Gregoratti, "Vito Messina, Jafar Mehr Kian. "The sanctuary and cemetery of Shami: research of the Iranian-Italian joint expedition in Khuzistan at Kal-e Chendarin"', Abstracta Iranica [Online],

Volume 42-43 | 2021, document 1, Online since 30 December 2020, connection on 06 January 2023.

URL: http://journals.openedition.org/abstractairanica/51787 ; DOI: https://doi.org/10.4000/

abstractairanica.51787

This text was automatically generated on 6 January 2023.

All rights reserved 
Vito Messina, Jafar Mehr Kian. “The sanctuary and cemetery of Shami: research of the Iranian-Italian joint expedition in Khuzistan at Kal-e chendarin"

Leonardo Gregoratti 


\section{REFERENCES}

Vito Messina, Jafar Mehr Kian. "The sanctuary and cemetery of Shami: research of the Iranian-Italian joint expedition in Khuzistan at Kal-e Chendarin" in P.B. Lurje (ed.).

Proceedings of the Eighth European Conference of Iranian Studies, Held on 14-19 September 2015 at the State Hermitage Museum and Institute of Oriental Manuscripts, Russian Academy of Sciences, in St Petersburg, Volume I. Saint Petersburg: The State Hermitage, 2019, p.

271-285

1 The authors are the co-directors of the Iranian-Italian archaeological Expedition in Khuzistan, south-west Iran, the seat of the kingdom of Elymais, a Parthian vassal state ruled by a local dynasty. In this paper written for the ECIS conference in 2014, they present the very first observation about the site of Kal-e Chendar, in the valley of Shami, where the famous Shami Prince bronze statue was discovered. The report describes the terraces and the mud-brick structures individuated by A. Stein in the 30s. Five underground tombs found in the proximity of the terrace are described containing sherds of glazed pottery. According to the authors, the tombs contained the spoils of members of the local aristocracy. The striking element is the lack of any trace of settlement. The isolated site seems to include the terrace/sanctuary and the necropolis only.

\section{AUTHORS}

\section{LEONARDO GREGORATTI}

Durham University 